\title{
PEUBAH-PEUBAH YANG MEMENGARUHI PEMBELI MENGGUNAKAN GERAI VIRTUAL FESYEN
}

\author{
Verena Winardi Kusumo \\ Magister Manajemen, Universitas Kristen Satya Wacana \\ Disetujui 24 November 2017
}

\begin{abstract}
E-tailers need to know what are customer's preferences to use online shop for fashionable products. So the purpose of this research is to describe the impact of independent variables like perceived-price, word-of-mouth, perceived-site-quality, perceived-vendor-reputation, structural assurance, brand image, and buyer attitude in using online shop. The sample of the study consist of 180 respondents by using purposive sampling method. Primary data will be analyzed by SEM (Structural Equation Modelling). The results show that buyer attitude is directly affected by perceived-price. Brand image is affected by perceived-vendor-reputation and structural assurance. Buyer attitude is affected by brand image. Using online shop variable is affected by buyer attitude. Other result shows that brand image isn't affected by word-of-mouth and perceived-site-quality..
\end{abstract}

Keywords: behavior, price, WOM, quality, reputation, assurance

\begin{abstract}
ABSTRAK
Para peritel-el perlu tahu apa yang mendasari pembeli menggunakan gerai virtual untuk berbelanja produk fesyen. Oleh karena itu, tujuan penelitian ini yaitu untuk mendeskripsikan pengaruh dari harga-terpersepsi, getok-tular, kualitas-situs-terpersepsi, reputasi-vendor-terpersepsi, keterjaminan struktural, citra merek, dan sikap pembeli terhadap penggunaan gerai virtual. Sampel penelitian berjumlah 180 orang responden diambil dengan menggunakan metode purposive sampling. Data primer dianalisis dengan menggunakan SEM (Structural Equation Modelling). Penelitian ini menemukan bahwa sikap pembeli dipengaruhi oleh harga-terpersepsi. Citra merek dipengaruhi oleh reputasi-vendorterpersepsi dan keterjaminan struktural. Sikap pembeli dipengaruhi oleh citra merek. Penggunaan gerai virtual dipengaruhi oleh sikap pembeli. Hasil lain menunjukkan bahwa citra merek tidak dipengaruhi oleh getok-tular dan kualitas-situs-terpersepsi.
\end{abstract}

Kata kunci: perilaku, harga, GT, kualitas, reputasi, keterjaminan

\section{PENDAHULUAN}

Globalisasi adalah kecenderungan umum terintegrasinya kehidupan masyarakat domestik/lokal ke dalam komunitas global di berbagai bidang (Arfani, 2004). Globalisasi membuat persaingan antar perusahaan semakin ketat.

\footnotetext{
*Korespondensi Penulis:

E-mail: verenalian94@gmail.com
}

Perusahaan yang mampu bersaing adalah perusahaan yang mengimplementasikan teknologi ke dalam perusahaannya (Almilia dan Robahi, 2009). Oleh karena itu muncul lah dagang elektronik (dagang-el), suatu proses dalam membeli dan menjual berbagai produk secara elektronik dari perusahaan ke pengguna akhir (B2C), perusahaan ke perusahaan (B2B), pengguna akhir ke perusahaan (C2B), atau pun pengguna akhir ke pengguna akhir (C2C) dengan menggunakan komputer sebagai 
perantara transaksi bisnis yang dilakukan (Laudon dan Laudon, 1998).

Dagang-el pada dasarnya adalah perusahaan dagang yang berbasis pada $9 \mathrm{P}$ terdiri atas Produk (Product), Harga (Price), Tempat (Place), Promosi (Promotion), Orang (People), Proses (Process), Bukti Fisik (Physical Evidence), Produk Berpangkalan Atom (Atom-based Product), dan Produk Berpangkalan Bit (Bit-Based Product) (Ihalauw, 2014). Menurut data Badan Pusat Statistik (BPS) terkini, setidaknya ada 82 juta orang atau sekitar 30\% penduduk Indonesia berbisnis melalui dagang elektronik ini. Dunia maya yang semakin berkembang mendorong ASEAN berfokus pada dagang elektronik, di mana gagasannya tercantum dalam Cetak Biru ASEAN (Sekretariat ASEAN, 2008). Salah satu pilar untuk membuat ekonomi yang lebih kompetitif adalah mengembangkan dagang elektronik. ASEAN harus meningkatkan legislasi dan regulasi untuk dagang elektronik, mengadopsi isu terbaru terkait dengan aktivitas dagang elektronik, meningkatkan implementasi transaksi elektronik dengan menggunakan tanda tangan digital, serta melanjutkan untuk menambah kapasitas bangunan dan berbagi informasi antar anggota ASEAN dalam meningkatkan aktivitas infrastruktur legal (Sekretariat ASEAN, 2008).

Dagang-el di Indonesia juga berkembang karena pengaruh modernisasi dari generasi $\mathrm{X}, \mathrm{Y}$ dan $\mathrm{Z}$. Walau pun generasi $X$ merupakan generasi yang lahir pada tahun 1965 hingga tahun 1980 (Hunusalela dan Hidayat, 2013), generasi ini dinilai cukup mahir menggunakan gawai dan mampu beraktivitas menggunakan Internet. Lalu setelah itu muncul generasi $Y$ yang merupakan generasi yang lahir pada tahun 1981 hingga tahun 2000 (Hunusalela dan Hidayat, 2013). Penguasaan teknologi terutama peralatan elektronik, gawai dan sistem komputerisasi menjadi hal yang lumrah dan berdampak pada cara pandang generasi tersebut yang lebih mengutamakan hasil ketimbang dengan proses (Luntungan et al., 2014). Ada pula generasi Z yaitu generasi yang lahir pada tahun 2000 ke atas (Mahani dan Nazlinda, 2015). Menurut mereka, generasi $\mathrm{Z}$ merupakan generasi dengan teknologi yang mulai melayari Internet dan situs seiring dengan usia mereka sejak mereka masih belum bercakap. Kemahiran menggunakan teknologi dan komunikasi virtual oleh generasi $\mathrm{X}, \mathrm{Y}$ dan $\mathrm{Z}$ membuat dagang elektronik menjamur.

Dagang elektronik yang menjamur berdampak pada strategi bisnis perusahaan dan menyebabkan perilaku konsumen dalam mengambil keputusan berbelanja berubah. Perilaku konsumen berubah disebabkan oleh beragam faktor. Menurut Setiadi (Subianto, 2007), faktor-faktor internal individu yang memengaruhi perilaku konsumen adalah: motivasi, kepribadian, pembelajaran, sikap, dan persepsi konsumen. Selain itu, keputusan beli pelanggan merupakan tanggapan perilaku yang diterima atas stimulan konsumen, meliputi aspek produk, harga, promosi, dan distribusi (Noviyarto, 2010). Beberapa penelitian mengenai perilaku konsumen pada gerai virtual telah dilakukan. Mantansari et al. (2015) menemukan bahwa kelompok acuan menyebabkan perubahan sikap pembeli dalam memilih telepon seluler. Komunikasi kelompok acuan tersebut dinamakan getoktular. Penelitian Pujastuti et al. (2014) menyimpulkan bahwa kualitas-situsterpersepsi dan keterjaminan struktural berpengaruh pada kepercayaan konsumen untuk berbelanja di dagang-el fesyen, namun reputasi vendor tidak berpengaruh pada kepercayaan konsumen.

"Perilaku Pembelian Melalui Internet" (Widiyanto dan Prasilowati, 2015) merupakan studi untuk menyelidiki atribut dalam perilaku pembelian daring. Atribut seperti kemenarikan desain situs dan reputasi vendor melalui sikap pembeli memengaruhi keputusan belanja daring, sedangkan persepsi kemudahan transaksi melalui sikap pembeli tidak berpengaruh signifikan terhadap keputusan belanja daring. Kotler dan Keller (2013) mengatakan bahwa sikap terhadap belanja 
daring mencerminkan tanggapan konsumen atas sistem belanja daring yang ditawarkan. Beragam faktor yang telah dibahas berguna bagi peritelan-el menciptakan keunggulan kompetitif supaya dapat bertahan di pasar virtual. Peritelan-el perlu tahu apa yang mendasari pembeli menggunakan gerai virtual untuk berbelanja produk fesyen.

Beberapa gagasan di atas memunculkan masalah penelitian yaitu tentang peubah-peubah yang memengaruhi pembeli menggunakan gerai virtual untuk berbelanja produk fesyen. Berdasarkan masalah penelitian tersebut, maka peneliti merumuskannya lebih rinci ke dalam persoalan-persoalan penelitian sebagai berikut (1) Apakah harga-terpersepsi memengaruhi penggunaan gerai virtual? (2) Apakah getok-tular memengaruhi citra merek? (3) Apakah reputasi-vendorterpersepsi memengaruhi citra merek? (4) Apakah reputasi-vendor-terpersepsi memengaruhi sikap pembeli? (5) Apakah kualitas-situs-terpersepsi memengaruhi sikap pembeli? (6) Apakah keterjaminan struktural memengaruhi sikap pembeli? (7) Apakah citra merek memengaruhi penggunaan gerai virtual? dan (8) Apakah sikap pembeli memengaruhi penggunaan gerai virtual? Tujuan penelitian ini yaitu untuk mendeskripsikan pengaruh: (1) Harga-terpersepsi terhadap penggunaan gerai virtual (2) Getok-tular terhadap citra merek (3) Reputasi-vendor-terpersepsi terhadap citra merek (4) Reputasi-vendorterpersepsi terhadap sikap pembeli (5) Kualitas-situs-terpersepsi terhadap sikap pembeli (6) Keterjaminan struktural terhadap sikap pembeli (7) Citra merek terhadap penggunaan gerai virtual dan (8) Sikap pembeli terhadap penggunaan gerai virtual. Lalu manfaat penelitian ini yaitu (1) memberikan informasi bagi perusahaan mengenai peubah-peubah yang memengaruhi pembeli dalam menggunakan gerai virtual fesyen, sehingga dapat membantu merancang strategi pemasaran untuk meningkatkan kinerja perusahaan dalam mengembangkan dan meningkatkan layanan dan kualitas gerai virtual, serta (2) landasan untuk penelitian selanjutnya di bidang pemasaran khususnya gerai virtual.

\section{TELAAH PUSTAKA}

\section{Perilaku Konsumen}

Menurut Ebert dan Griffin (2011), perilaku konsumen adalah semua kegiatan, tindakan, serta proses psikologi yang mendorong tindakan tersebut pada saat sebelum membeli, ketika membeli, menggunakan, menghabiskan produk atau jasa, dan setelah melakukan hal-hal di atas maka dilakukan evaluasi. Pengetahuan mengenai perilaku konsumen akan membantu perusahaan mengetahui orientasi konsumen, fakta-fakta perilaku konsumen, dan teori yang membimbing proses berpikir konsumen. Kotler dan Keller (2013) mengemukakan bahwa perilaku konsumen dipengaruhi oleh faktor budaya, sosial, pribadi, dan psikologis.

Tampilan produk fesyen melalui dagang-el menimbulkan beragam persepsi bagi pembeli. Informasi yang sama bisa dipersepsikan berbeda oleh individu yang berbeda (Sangadji dan Sopiah, 2013). Persepsi tersebut akan memengaruhi keputusan beli seorang individu. Ada pula gaya hidup sebagian generasi $\mathrm{X}, \mathrm{Y}$ dan $\mathrm{Z}$ yang akrab dengan teknologi akan mengubah perilaku pelanggan. Pelanggan kini cenderung menginginkan hal praktis tanpa harus berinteraksi langsung. Manfaat terpersepsi dan kepercayaan merupakan faktor yang memengaruhi pembelian melalui media sosial (Hajli, 2014). Selain itu risiko terpersepsi, sikap, pemantauan kebiasaan terpersepsi, inovasi yang spesifik, serta norma subjektif dinilai akan memengaruhi perilaku konsumen (Javadi et al., 2012).

Generasi $\mathrm{X}, \mathrm{Y}$ dan $\mathrm{Z}$ mungkin tidak hanya menjadi pembeli. Mereka dapat menjadi distributor atau pengusaha dagangel. Risiko yang muncul adalah ketika pengguna hanya merupakan distributor, pengguna tidak dapat secara pasti menjamin kondisi produk sesuai dengan gambar atau pun memastikan bahwa produk yang dibeli 
akan dikirimkan oleh pemasok utama. Oleh karena itu, menurut Widiyanto dan Prasilowati (2015), untuk meminimalkan risiko yang ada, maka pihak penjual mau pun pembeli perlu melakukan tindakan yang lebih berhati-hati, misalnya memastikan adanya sertifikat bisnis daring. Bisnis yang aman akan membangun kepercayaan pada pembeli. Kepercayaan konsumen merupakan fondasi untuk menjaga hubungan yang baik dengan konsumen dalam jangka panjang (Sangadji dan Sopiah, 2013).

\section{Dagang-el}

Dagang-el adalah proses pembelian, penjualan atau pertukaran produk, jasa dan informasi melalui jaringan komputer (Irmawati, 2011). Dagang-el dapat didefinisikan berdasarkan 4 perspektif menurut Kalakota dan Whinston (1997) yaitu:

1. Perspektif komunikasi: dagang-el merupakan pengiriman informasi, produk/ layanan, atau pembayaran melalui jalur telepon, jaringan komputer atau sarana elektronik lainnya.

2. Perspektif proses bisnis: dagang elektronik merupakan aplikasi teknologi menuju otomisasi transaksi dan aliran kerja perusahaan.

3. Perspektif layanan: dagang elektronik merupakan salah satu alat yang memenuhi keinginan perusahaan, konsumen dan manajemen dalam memangkas biaya jasa ketika meningkatkan mutu barang dan kecepatan layanan.

4. Perspektif daring: dagang elektronik berkaitan dengan kapasitas jual beli produk dan informasi di Internet dan jasa daring lainnya.

Produk pada dagang-el yang berupa produk elektronik bersifat pasti untuk spesifikasi produknya, berbeda pada gerai virtual fesyen. Konsumen hanya dapat mengira-ngira dengan deskripsi ukuran, warna, mau pun bahan yang tertera, sedangkan konsumen tidak tahu pakaian tersebut sudah sesuai dengan keinginan konsumen atau belum (Pujastuti et al., 2014). Gambar produk fesyen terbaik digunakan sebagai rangsangan pemasaran. Rangsangan pemasaran adalah setiap komunikasi atau stimuli fisik yang didesain untuk memengaruhi konsumen (Sangadji dan Sopiah, 2013). Ada pun risiko belanja di dagang elektronik adalah rusaknya barang akibat pengiriman atau cacad produksi. Barang yang dipesan tidak sampai ke pembeli karena hilang saat pengiriman dan keterlambatan pengiriman. Selain itu adanya penipuan oleh penjual (Turban et al., 2008). Para pembeli sangat berhati-hati dengan ancaman kecurangan daring tersebut. Hal tersebut terjadi karena pada dasarnya banyak pembeli tidak percaya pada dagang-el, kecuali jika perusahaan dapat membangun kepercayaan pengunjung atas dagang-el. Oleh karena itu, pengunjung mulai mengevaluasi kredibilitas situs sesaat setelah mereka memasuki situs tersebut (Pujastuti et al., 2014).

\section{Peritelan-Elektronik (Peritelan-EI)}

Menurut Turban et al. (2008), peritelan-el didefinisikan sebagai gerai virtual yang terhubung dengan Internet. Peritelan daring (peritelan-el) tidak mengharuskan interaksi tatap muka langsung antara penjual dan pembeli di lokasi fisik yang sama. Ada pun tiga aktivitas utama dalam peritelan-el menurut Dawn dan Kar (2011) yaitu:

1. Evaluasi produk atau mengumpulkan informasi mengenai fasilitas produk

2. Fungsi pembelian daring

3. Kapabilitas dalam mengirimkan produk.

Gupta (2013) menemukan bahwa peritelan-el merupakan bisnis yang bagus dan dapat dikapitalisasi dengan cepat. Ada pun Florenthal (2007) membagi tiga tingkat interaksi yang digunakan para peritel-el dalam merumuskan strateginya, yaitu produk, proses, dan kemitraan (partnership). Tingkat produk meliputi strategi harga dan keragaman produk. 
Tingkat proses untuk membentuk persepsi pembeli dengan menyediakan agen elektronik, sedangkan tingkat kemitraan fokus kepada hubungan jangka panjang untuk kesetiaan, komitmen, dan kepercayaan kepada pembeli. Selain itu, peritelan-el harus memiliki teknologi yang lebih baik untuk pelayanan yang handal dan keunikan dalam mengembangkan bisnis daring. Selain itu, produk yang ditawarkan lebih beragam dan spesifik karena menyesuaikan kebutuhan pelanggan. Pembayaran untuk transaksi jual beli secara daring juga dipermudah dengan menggunakan kartu kredit atau transfer dana elektronik. (Chandra dan Sunitha, 2012).

\section{Produk Fesyen}

Menurut Kamus Besar Bahasa Indonesia (2017), fesyen (mode) merupakan bentuk nomina yang bermakna ragam cara atau bentuk terbaru pada suatu waktu tertentu (tata pakaian, potongan rambut, corak hiasan, dsb). Fesyen tidak terpisahkan dari selera masyarakat yang dipengaruhi oleh perkembangan sosial budaya tertentu dan dalam rentang waktu tertentu. Produk fesyen adalah sebuah produk yang mempunyai ciri-ciri khusus yang tepat dan memiliki gaya yang sedang cenderungan dalam suatu kurun waktu. Produk fesyen memiliki daur hidup produk, sehingga dapat mengalami penurunan penjualan. Hal yang memengaruhi adalah adanya gaya fesyen terbaru yang menjadi cenderungan sehingga gaya fesyen yang lama tersingkirkan. Selain itu, penurunan penjualan disebabkan oleh karakteristik masing-masing pembeli yang berbeda, sehingga belum tentu seseorang akan terpengaruh dengan gaya terbaru (Savitrie, 2008).

\section{Penggunaan Gerai Virtual}

Penggunaan gerai virtual merupakan sarana berbasis Internet yang dipakai untuk membuat proses belanja lebih sederhana, efisien, cepat, dan bebas hambatan bisnis yang besar (Turban et al., 2008). Teknologi unggul dalam hal memberikan informasi dan komunikasi untuk metode belanja yang baru, dan meningkatkan pertumbuhan untuk dagang elektronik yang mana pembeli tidak mau repot ke gerai riil (Bigne, 2008). Pembeli kini dapat melakukan aktivitas melalui daring untuk mencari, memilih, membeli, menggunakan, serta mengevaluasi produk atau jasa demi memenuhi kebutuhan dan keinginan.

Shim et al. (2002) menjelaskan bahwa perilaku pembeli dagang elektronik sangat bergantung pada ketersediaan informasi, kemenarikan desain situs dan kemudahan dalam melakukan transaksi dagang. Menurut Pujastuti et al. (2014), kepercayaan konsumen yaitu kualitas-situsterpersepsi, reputasi-vendor-terpersepsi, serta keterjaminan struktural memengaruhi perilaku konsumen terhadap perdagangan virtual. Keputusan beli pelanggan untuk membeli atau tidak membeli merupakan tanggapan perilaku yang diterima atas stimulan konsumen, meliputi aspek produk, harga, promosi, dan distribusi (Noviyarto, 2010). Selain itu, getok-tular yang melibatkan dua bahkan lebih individu seperti anggota kelompok acuan, atau konsumen dan tenaga penjual yang mana semua orang mempunyai pengaruh atas pembelian (Jatmika, 2014). Faktor-faktor tersebut akan memengaruhi sikap pembeli baik secara langsung mau pun tidak langsung.

\section{Harga-Terpersepsi}

Harga ialah jumlah uang yang perusahaan tetapkan untuk produk (barang atau jasa), atau jumlah nilai yang pembeli tukarkan demi memperoleh manfaat dari kepemilikan atau penggunaan produk tersebut. Informasi harga yang dipahami oleh konsumen membentuk persepsi untuk masing-masing individu. Persepsi mengenai harga merupakan penilaian pelanggan dan bentuk emosional yang terasosiasi mengenai apakah harga yang ditawarkan oleh penjual dan harga yang dibandingkan dengan pihak lain masuk diakal, dapat diterima atau dapat dibuktikan (Xia et. al., 2004). Semakin positif harga-terpersepsi, 
maka konsumen dimungkinkan akan memengaruhi pembeli dalam menggunakan gerai virtual. Pembeli akan mencari merek dagang atau gerai virtual dengan kualitas produk fesyen yang bagus namun dengan harga yang lebih terjangkau. Dagang-el yang menggunakan jaringan Internet akan memudahkan konsumen dalam membandingkan harga produk fesyen antar gerai virtual.

\section{Getok-Tular}

Getok-tular adalah komunikasi antar perseorangan melibatkan dua bahkan lebih individu seperti anggota kelompok acuan atau konsumen dan tenaga penjual di mana semua orang berpengaruh atas pembelian (Jatmika, 2014). Getok-tular memiliki tingkat keterpercayaan yang tinggi dari iklan komersial (Herr et al., 1991). Ada pun 3 (tiga) tahapan getok-tular (Sumardi, 2009) adalah TAPS ( Talking, Promoting, dan Selling) yaitu:

1. Membicarakan adalah tahapan di mana seorang konsumen membicarakan sebuah produk atau merek kepada konsumen lain.

2. Mempromosikan ketika seorang konsumen bukan hanya sekedar membicarakan merek/ produk tapi juga bersedia untuk mempromosikannya kepada konsumen lain.

3. Menjual adalah tahapan dimana seorang konsumen bersedia menjualkan merek/ produk tersebut kepada orang lain.

Internet memunculkan istilah getok-tular-elektronik (GTe) di mana promosi ini merupakan hasil dari evolusi komunikasi tradisional. Getok-tular akan menyebabkan konsumen memiliki peran aktif yang lebih tinggi dalam siklus rantai nilai, sehingga mampu memengaruhi produk, harga, dsb berdasarkan preferensi masing-masing individu. Getok-tular juga akan memengaruhi citra merek dan minat beli (Jatmika, 2014). Semakin positif getoktular oleh dagang-el fesyen, maka akan memengaruhi citra merek.

\section{Reputasi-Vendor-Terpersepsi}

Reputasi merupakan keseluruhan kualitas atau karakter yang terlihat dan juga dinilai oleh individu secara umum (Josang, 2007). Reputasi-vendor-terpersepsi merupakan suatu atribut yang diberikan kepada penjual berdasarkan pada informasi dari orang atau sumber lain (Pujastuti, et. al, 2014). Reputasi-vendor-terpersepsi memberikan keyakinan kepada pihak lain mengenai kemampuan, integritas dan goodwill (Subiantara dan Sukoharsono, 2014). Reputasi penting untuk membangun kepercayaan seorang pembeli terhadap penjual karena pembeli mungkin belum pernah memiliki pengalaman berbelanja dengan penjual. Dapat disimpulkan bahwa reputasi-vendor-terpersepsi merupakan proses pelanggan menilai keseluruhan kualitas dan karakter yang dimiliki oleh tiap vendor dalam hal kemampuan, integritas dan goodwill.

Reputasi mampu menciptakan citra di mata konsumen. Citra perusahaan merupakan persepsi seseorang pada suatu perusahaan yang terbentuk dengan informasi yang didapat dari berbagai sumber yang dipercaya (Mira, 2013). Informasi positif yang diterima pembeli mengenai penjual dapat mengurangi kekhawatiran terhadap risiko dan ketidakamanan peritelan-el. Reputasi berdasarkan loloh balik dapat menguatkan sikap seseorang terhadap belanja daring ( $\mathrm{Li}$ et al., 2002). Oleh karena itu, reputasivendor-terpersepsi yang positif akan memengaruhi sikap pembeli dan citra merek.

\section{Kualitas-Situs-Terpersepsi}

Kualitas-situs-terpersepsi adalah penilaian akan kualitas situs gerai virtual (Pujastuti, et al., 2014). Situs yang memiliki tampilan bagus, menarik, dan berkesan profesional akan memberikan rasa nyaman dan meningkatkan kepercayaan kepada pelanggan. Desain konten situs sebaiknya berisi komponen informasi sebuah situs, barang atau jasa yang ditawarkan, baik secara tekstual mau pun grafis. Menurut Pujastuti, et al. (2014), kualitas informasi 
merupakan faktor penting dalam kepercayaan daring, kepuasan pelanggan, dan kesetiaan. Kualitas-situs-terpersepsi akan memengaruhi keputusan beli melalui peubah mediasi sikap belanja daring (Widiyanto dan Prasilowati, 2015). Kriteria sebuah situs dengan kualitas yang baik adalah interaktif, representatif, ringkas dan sederhana, aman dan terjamin, serta memiliki desain yang menarik (Assegaff, 2009). Semakin positif kualitas-situsterpersepsi akan memengaruhi sikap pembeli.

\section{Keterjaminan Struktural}

Keterjaminan struktural merupakan penilaian subjektif pelanggan terhadap konsekuensi negatif yang akan diterima ketika melakukan pembelian (Jarvenpaa et. al., 2000). Menurut Sha (2009), keterjaminan struktural adalah tingkat kepercayaan pelanggan mengenai struktur institusi meliputi garansi, aturan, janji, jalur hukum, serta prosedur lain guna menyukseskan penjual. Keterjaminan struktural pada gerai virtual dapat diukur melalui seberapa canggihnya sistem keamanan atau susunan teknologi yang digunakan. Gerai virtual yang baik akan menjamin bahwa situs jual beli berjalan aman. Keterjaminan struktural dapat dibagi menjadi 2 (dua) yaitu internal dan eksternal (Pujastuti et al., 2014). Keterjaminan struktural internal meliputi kebijakan gerai virtual mengenai garansi uang kembali, kebijakan privasi, atau peraturan pengiriman barang. Keterjaminan struktural eksternal adalah sertifikasi keamanan dan privasi setelah lulus evaluasi situs yang disediakan oleh pihak ketiga. Semakin positif keterjaminan struktural akan memengaruhi sikap pembeli.

\section{Citra Merek}

Merek adalah nama, istilah, tanda, lambang, atau desain, atau kombinasinya, yang dimaksudkan untuk mengidentifikasikan barang atau jasa dari suatu penjual atau kelompok penjual dan membedakan produk atau jasa dari para pesaing (Kotler dan Keller, 2013), sehingga menurut mereka, citra merek adalah persepsi tentang merek yang merupakan refleksi memori konsumen akan asosiasinya pada merek tersebut. Citra merek adalah kunci untuk membangun ekuitas merek melalui persepsi dan perasaan terhadap merek dan berdampak pada perilaku konsumen (Zhang, 2015). Menurut Kerby (Sukma et al., 2016), elemen yang terkandung dalam citra merek yaitu:

1. Ketahanan (tenacity) berkaitan dengan kualitas dan citra merek produk itu sendiri.

2. Kesesuaian (congruence) berkaitan dengan kesesuaian antara citra merek dan karakteristik merek.

3. Keseksamaan (precision) menentukan seberapa tepat dan jelasnya citra yang ingin ditampilkan.

4. Konotatif (connotative) merupakan pendapat konsumen dari kepribadian produk yaitu dari semua karakteristik merek produk sejenis yang diterima, konsumen menemukan merek produk yang satu berbeda dengan merek produk yang lainnya.

Informasi mengenai citra merek didapat dari 2 (dua) cara yaitu pengalaman konsumen secara langsung dan persepsi konsumen. Informasi positif yang diterima pembeli mengenai penjual dapat mengurangi kekhawatiran terhadap risiko dan ketidakamanan peritelan-el. Pengembangan citra merek membutuhkan beberapa perubahan program pemasaran yang dapat meningkatkan kekuatan dan keunikan dari suatu merek yang akan meningkatkan citra merek tersebut. Pembentukan citra merek dipengaruhi oleh kualitas produk yang dihasilkan, layanan yang disediakan, reputasi perusahaan, kebijaksanaan perusahaan, serta kegiatankegiatan pemasaran perusahaan. Semakin positif citra merek yang dimiliki gerai virtual maka akan memengaruhi penggunaan gerai virtual karena pembeli beranggapan bahwa berbelanja produk fesyen akan terjamin kualitasnya. 


\section{Sikap Pembeli}

Prasad dan Aryasri (2009) mengemukakan bahwa sikap merupakan suatu bentuk perasaan yang bersifat favourable atau unfavourable. Sikap mencerminkan rasionalitas pembeli mengenai suatu produk. Vijayasarathy dan Jones (Rumlus dan Junaedi, 2014), mendefinisikan sikap pembeli tentang sejauh mana konsumen suka belanja daring dan menganggap hal itu menjadi gagasan yang baik. Kuat tidaknya keinginan sesorang untuk berbelanja menggunakan Internet akan bergantung pada besar kecilnya manfaat yang diterima saat berbelanja secara daring dibanding dengan risiko yang mungkin dialaminya ( $\mathrm{Yu}$ dan $\mathrm{Wu}, 2007)$.

\section{Breckler}

mengidentifikasikan tiga dimensi sikap pembeli dalam menggunakan gerai virtual meliputi dimensi kognitif, afektif dan konatif. Dimensi kognitif adalah suatu dimensi yang mengacu pada keyakinan individu terhadap suatu objek. Dimensi afektif merupakan suatu dimensi yang melibatkan perasaan oleh stimulus dari dalam hati individu. Sementara itu, dimensi konatif berkaitan dengan kecenderungan seorang individu berperilaku atas suatu objek. Oleh karena itu dapat disimpulkan bahwa sikap pembeli dalam menggunakan gerai virtual adalah sikap suka dan tidak suka pembeli terhadap toko daring dengan membandingkan manfaat yang akan diterima dan yakin bahwa untuk belanja adalah ide bagus karena produk yang dibeli juga bagus. Semakin positif sikap pembeli maka akan memengaruhi penggunaan gerai virtual.

\section{Model Penelitian}

Berdasarkan telaah pustaka di atas, maka dihasilkan model penelitian yang terlihat di Gambar 1.

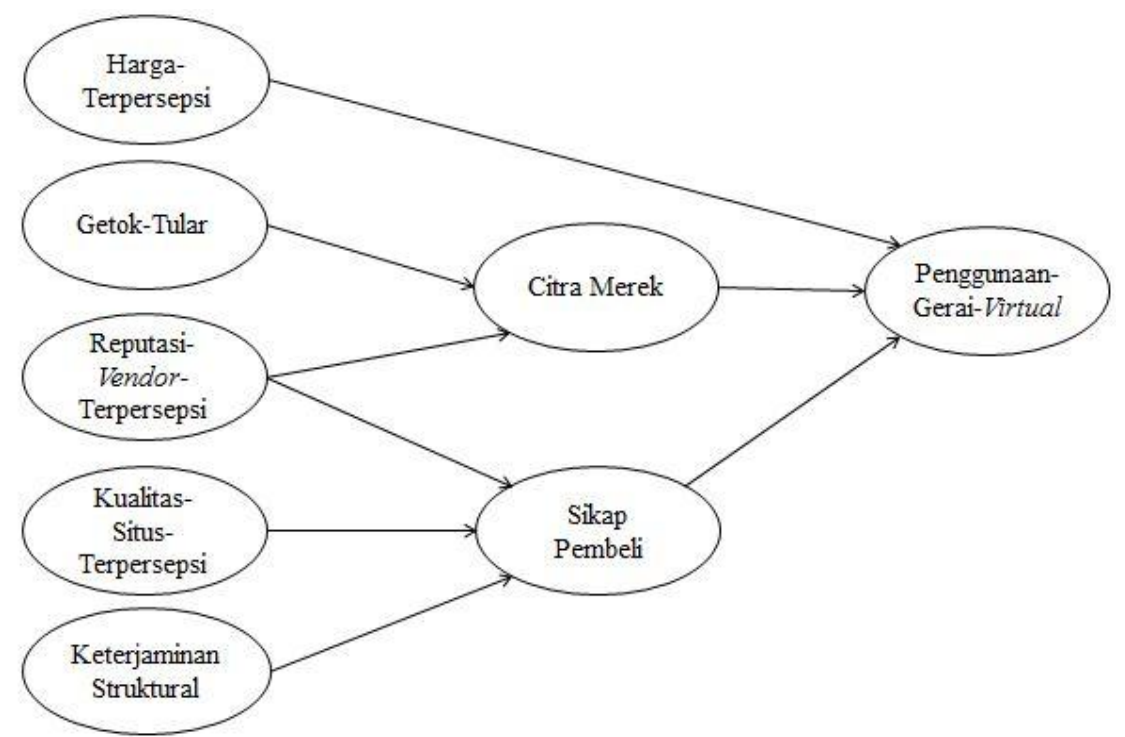

Gambar 1. Model Penelitian (2017)

Sumber: Proposisi penelitian yang telah diolah (2017)

\section{METODE PENELITIAN}

Penelitian ini deskriptif kuantitatif dan menggunakan sumber data primer yang dikumpulkan dengan kuesioner kepada pembeli yang akan dan/ atau sudah menggunakan gerai virtual untuk berbelanja produk fesyen. Populasi penelitian adalah seluruh generasi $\mathrm{X}, \mathrm{Y}$ dan $\mathrm{Z}$ di kota Salatiga. Penelitian ini membentuk sampel non probabilitas dengan metode purposive sampling, berdasarkan 
kriteria, yaitu generasi $\mathrm{X}, \mathrm{Y}$ dan $\mathrm{Z}$ yang bekerja mau pun masih studi, umur berkisar 15 tahun hingga 50 tahun, mempunyai Internet untuk mengakses dagang-el, tahu mengenai gerai virtual fesyen, dan berada di Kota Salatiga.

Hair et al., (2012) memberikan pedoman bahwa jika jumlah konstruk kurang atau sama dengan tujuh dan modest communalities, maka sampel penelitian yang dibutuhkan minimal 150 orang responden di mana 30 buah indikator dikalikan dengan konstanta 5. Namun mengingat bahwa nantinya mungkin ada data yang hilang atau salah, maka peneliti menaikkan jumlah sampel sebanyak 20\% dari 150 orang responden, sehingga penelitian ini mengambil 180 orang responden.

Tabel 1. Pengukuran Konsep (Definisi Operasional)

\begin{tabular}{ll}
\hline \multicolumn{1}{c}{ Peubah } & \multicolumn{1}{c}{ Definisi } \\
\hline & \\
& $\begin{array}{l}\text { Penggunaan gerai virtual merupakan } \\
\text { proses, cara, perbuatan memakai sarana } \\
\text { berbasis Internet yang dipakai untuk } \\
\text { membuat proses belanja lebih } \\
\text { Virtual } \\
\text { (Turban et al., } \\
\text { 2008) }\end{array}$ \\
& $\begin{array}{l}\text { sederhana, efisien, cepat, dan bebas } \\
\text { hambatan bisnis yang besar. }\end{array}$
\end{tabular}

- Proses memakai Internet agar proses belanja lebih sederhana.

- Proses memakai Internet agar proses belanja lebih efisien.

- Proses memakai Internet agar proses belanja lebih cepat.

- Proses memakai Internet agar proses belanja bebas hambatan.

- Penilaian pelanggan tentang jumlah uang yang diberikan dengan yang ditawarkan untuk perolehan kepemilikan.

- Penilaian pelanggan

Harga-terpersepsi merupakan penilaian pelanggan dan bentuk emosional yang terasosiasi mengenai apakah jumlah uang yang diberikan demi perolehan kepemilikan atau manfaat produk dengan jumlah uang yang ditawarkan oleh penjual dapat diterima atau tidak. tentang jumlah uang yang diberikan dengan yang ditawarkan untuk manfaat produk.

- Emosi pelanggan tentang jumlah uang yang diberikan dengan yang ditawarkan untuk perolehan kepemilikan.

- Emosi pelanggan tentang jumlah uang yang diberikan dengan yang ditawarkan untuk manfaat produk.

- Pembicaraan antar perseorangan dengan kelompok referensi untuk merek produk.
Getok-tular

(Sumardi, 2009), (Jatmika, 2014)
Getok-tular adalah komunikasi antar perseorangan melibatkan dua bahkan lebih individu seperti anggota kelompok referensi untuk membicarakan, 


\begin{tabular}{ll}
\hline \multicolumn{1}{c}{ Peubah } & \multicolumn{1}{c}{ Definisi } \\
\hline & $\begin{array}{l}\text { mempromosikan, serta menjualkan } \\
\text { merek produk ke sesama konsumen. }\end{array}$ \\
& \\
& \\
Kualitas-situs- & $\begin{array}{l}\text { Kualitas-situs-terpersepsi } \\
\text { penilaian akan kualitas situs gerai } \\
\text { virtual dan desain konten situs } \\
\text { sebaiknya berisi komponen informasi } \\
\text { sebuah situs, barang atau jasa yang } \\
\text { ditawarkan, baik secara tekstual mau } \\
\text { 2014) }\end{array}$
\end{tabular}

Indikator

Promosi antar
perseorangan dengan
kelompok referensi untuk
merek produk.

- Penjualan atas merek produk untuk perseorangan dengan kelompok referensi.

- Penilaian desain konten terkait informasi situs secara tekstual.

Kualitas-situs- penilaian akan kualitas situs gerai terpersepsi virtual dan desain konten situs (Pujiastuti, et al, sebuah situs, barang atau jasa yang pun grafis.

- Penilaian desain konten terkait informasi situs secara grafis.

- Penilaian desain konten terkait informasi barang dan jasa secara tekstual.

- Penilaian desain konten terkait informasi barang dan jasa secara grafis.

- Penilaian pelanggan atas kualitas vendor.

Reputasi-vendorterpersepsi

(Josang, 2007), (Subiantara dan Sukoharsono, 2014)

Reputasi-vendor-terpersepsi merupakan proses pelanggan menilai keseluruhan kualitas dan karakter yang dimiliki oleh tiap vendor dalam hal kemampuan, integritas dan goodwill.

- Penilaian pelanggan atas kemampuan vendor.

- Penilaian pelanggan atas integritas vendor.

- Penilaian pelanggan atas goodwill vendor.

- Tingkat kepercayaan pelanggan tentang garansi.

Keterjaminan struktural adalah tingkat

Keterjaminan struktural (Sha, 2009) kepercayaan pelanggan mengenai struktur institusi meliputi garansi, aturan, janji, jalur hukum, serta prosedur lain guna menyukseskan penjual.
- Tingkat kepercayaan pelanggan tentang aturan institusi.

- Tingkat kepercayaan pelanggan tentang janji institusi.

- Tingkat kepercayaan pelanggan tentang jalur hukum.

- Persepsi pelanggan terhadap ketahanan

Citra merek (Kerby (2004) dalam Sukma et al., 2016), (Zhang, 2015)
Citra merek adalah persepsi dan perasaan pelanggan terhadap merek meliputi ketahanan, kesesuaian, keseksamaan, dan konotasi. merek.

- Persepsi pelanggan terhadap kesesuaian merek.

- Persepsi pelanggan terhadap keseksamaan 


\begin{tabular}{|c|c|c|}
\hline Peubah & Definisi & Indikator \\
\hline & & $\begin{array}{l}\text { merek. } \\
\text { - Persepsi pelanggan } \\
\text { terhadap konotasi merek. }\end{array}$ \\
\hline $\begin{array}{l}\text { Sikap Pembeli } \\
\text { (Vijayasarathy dan } \\
\text { Jones } \quad(2000) \\
\text { dalam Rumlus dan } \\
\text { Junaedi, 2014), } \\
\left(\begin{array}{l}Y u \text { dan } \\
\text { 2007) }\end{array}\right.\end{array}$ & $\begin{array}{l}\text { Sikap pembeli adalah kesukaan pembeli } \\
\text { terhadap toko daring dengan } \\
\text { memperkirakan manfaat yang akan } \\
\text { diterima dan keyakinan bahwa belanja } \\
\text { daring adalah ide bagus karena produk } \\
\text { yang dibeli juga bagus. }\end{array}$ & $\begin{array}{l}\text { - Kesukaan pembeli } \\
\text { terhadap manfaat yang } \\
\text { akan diterima. } \\
\text { - Keyakinan belanja daring } \\
\text { adalah ide bagus. } \\
\text { - Keyakinan belanja daring } \\
\text { diakibatkan oleh produk } \\
\text { bagus. }\end{array}$ \\
\hline
\end{tabular}

Sumber: Peneliti

Indikator untuk setiap peubah di atas menjadi butir pernyataan kuesioner. Penelitian ini menggunakan Skala Likert dengan 5 (lima) butir nilai, di mana Sangat Setuju $(S S)=5$, Setuju $(S)=4, \operatorname{Netral}(N)=$ 3 , Tidak Setuju $(\mathrm{TS})=2$, dan Sangat Tidak Setuju $($ STS $)=1$.

\section{Estimasi Model (Model Estimation)}

Metode estimasi yang digunakan adalah Maximum Likelihood. Metode estimasi tersebut memberikan estimasi parameter yang terbaik untuk 180 orang sampel tetapi harus memenuhi asumsi normalitas dan uji statistik deskriptif. Data dikatakan normal apabila $p$-value nya tidak lebih besar dari $+/-2.58$. Profil responden/ sifat keragaman data diketahui melalui daftar frekuensi, sedangkan indikator tiap peubah ditentukan melalui ukuran pemusatan data (rata-rata dan rerata) dan ukuran penyebaran data (nilai minimum, maksimum, batas/ range, dan simpangan baku). Rerata akan mencerminkan hasil untuk semua indikator ke dalam sebuah skala. Skala tersebut akan digunakan untuk mengetahui suatu nilai rerata, apakah sangat setuju, netral atau bahkan sangat tidak setuju.

\section{Pengukuran Model}

Pengukuran model dalam penelitian ini dilakukan dengan model pengukuran (outer model) dan model struktural (inner model). Model pengukuran meliputi uji kesahihan dan uji keandalan. Uji kesahihan diukur menggunakan nilai dari loading factor dan data dikatakan sahih, jika +/- 40 buah indikator memiliki nilai faktor loading lebih besar dari 0.7 (Hair et. al., 2012). Selain uji kesahihan, peneliti akan melakukan uji keandalan dengan menggunakan Alfa Cronbach. Data dikatakan handal jika nilai Alpha Cronbach lebih dari 0.7 untuk penelitian yang bersifat konfirmasi (Hair et. al., 2012).

Selanjutnya model penelitian akan dilihat goodness of fit (kelayakan model). Ada 3 ukuran untuk menilai kelayakan model yaitu (1) absolute fit indices meliputi chi-square, Goodness of Fit (GFI), dan Root Mean Square Error of Approximation (RMSEA), (2) incremental fit indices meliputi Adjusted Goodness of Fit (AGFI), Normal Fit Index (NFI), Comparative Fit Index (CFI), Incremental Fit Index (IFI), dan Relative Fit Indices (RFI), dan (3) parsimony fit indices meliputi Akaike's Information Criterion (AIC), Consistent Akaike Information Index (CAIC), Expected Cross Validation Index (ECVI), dan Parsimonious Goodness of Fit Index (PGFI). Menurut Hair et al., (2012), jika 4 sampai dengan 5 kriteria kelayakan model terpenuhi, maka hal tersebut sudah dianggap layak asalkan masing-masing 3 ukuran kelayakan model di atas terwakili. Setelah model penelitian fit atau layak, 
maka dilakukan uji hipotesis. Hipotesis diterima jika $p$-value memiliki nilai kurang dari tingkat signifikansi.

\section{HASIL DAN PEMBAHASAN}

Berdasarkan informasi pada gambar 1 , generasi $\mathrm{X}$ yang digunakan sebagai responden berjumlah 8 orang (4.4\%), generasi $\mathrm{Y}$ berjumlah 167 orang $(92,8 \%)$, serta generasi $\mathrm{Z}$ berjumlah 5 orang $(2,8 \%)$.

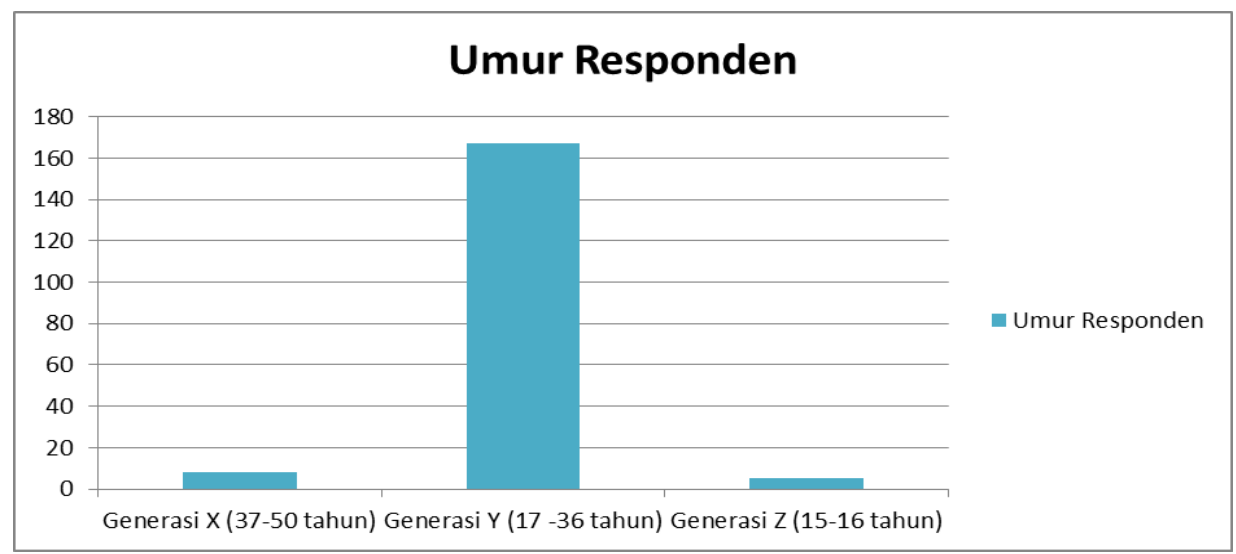

Gambar 2. Umur Responden $(n=180)$

Sumber: Data diolah (2017)

Berdasarkan informasi pada gambar 2, responden yang mengeluarkan pendapatan kurang dari Rp 500.000,sebanyak 38 orang (21.1\%), pendapatan antara Rp 500.000,- hingga Rp 1.500.000,sebanyak 87 orang (48.3\%), pendapatan antara Rp 1.500.000,- hingga Rp
3.000.000,- sebanyak 35 orang (19.5\%), pendapatan antara Rp 3.000.000,- hingga $\mathrm{Rp} 5.000 .000$ sebanyak 14 orang $(7.8 \%)$, serta pendapatan lebih dari Rp 5.000.000,sebanyak 6 orang $(3.3 \%)$.

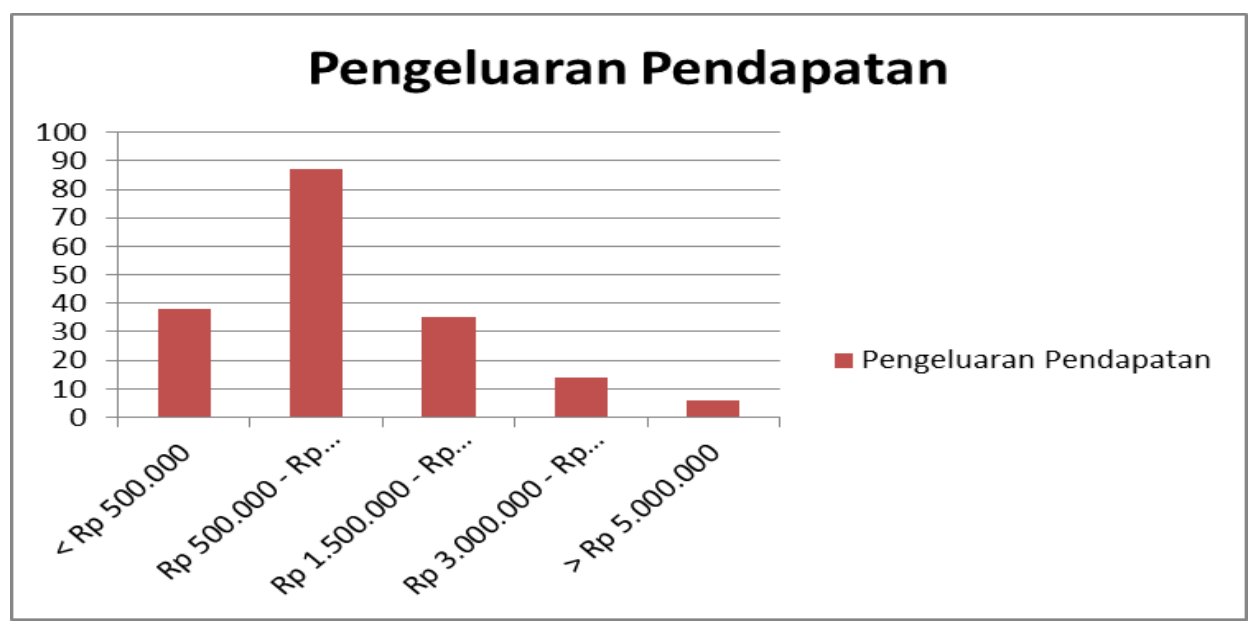

Gambar 3. Pengeluaran Pendapatan Responden $(n=180)$

Sumber: Data diolah(2017) 
Pada gambar 3, jumlah responden laki-laki sebanyak 92 orang, sedangkan perempuan hanya 88 orang. Pada jaman yang canggih dan modern ini, laki-laki pun ikut menyukai produk-produk fesyen dan berbelanja di gerai virtual untuk memudahkan proses belanja.

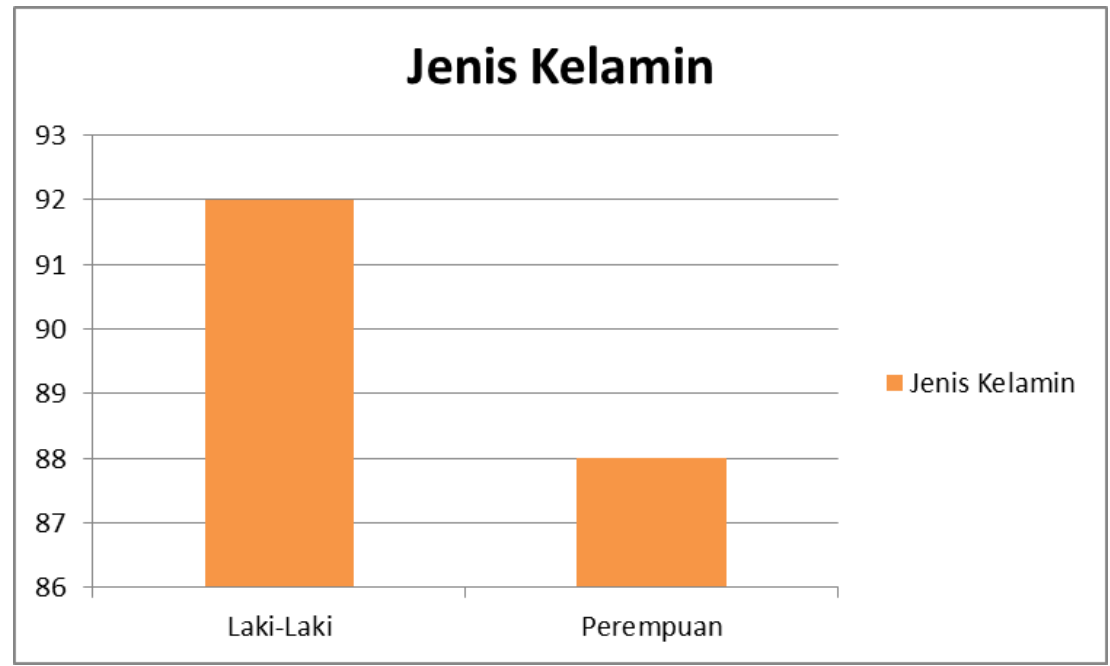

Gambar 4. Responden Menurut Jender $(n=180)$

Sumber: Data diolah (2017)

Gambaran yang dapat diambil melalui informasi mengenai karakteristik responden adalah pembeli gerai virtual mayoritas merupakan generasi $\mathrm{Y}$, memiliki pengeluaran pendapatan antara $\mathrm{Rp}$ 500.000,- hingga $\mathrm{Rp} 1.500 .000,-$, dan terbanyak laki-laki.
Model Penelitian Awal berdasarkan uji SEM (Structural Equation Modelling)

Gambar 5 merupakan model penelitian awal untuk diuji dengan menggunakan program Amos 2.20 


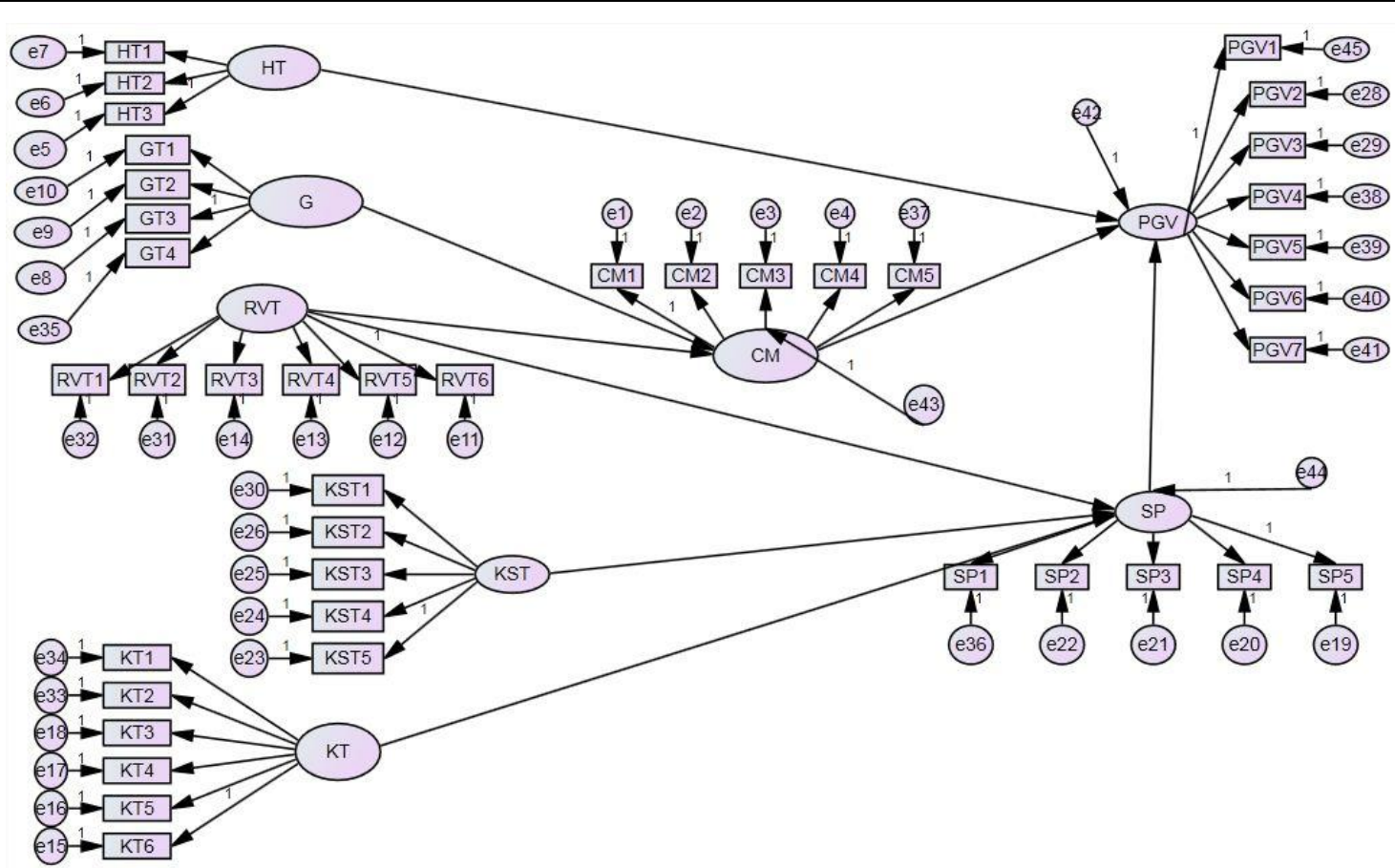

Gambar 5. Model Penelitian Awal Berdasarkan Uji SEM (n= 180)

Sumber: Data diolah (2017)

Keterangan: PGV = Penggunaan Gerai Virtual, HT = Harga-Terpersepsi, G = Getok-Tular, KST $=$ Kualitas-Situs-Terpersepsi, Reputasi-Vendor-Terpersepsi, KT = Keterjaminan Struktural, CM $=$ Citra Merek, $\mathrm{SP}=$ Sikap Pembeli

Model penelitian ini merupakan model awal pengolahan data sebelum dilakukan pengujian SEM lebih lanjut. Peubah gayut pada model di atas adalah PGV. Ada pula peubah-peubah bebas meliputi HT, G, KST, RVT, serta KT. Peubah bebas yang memengaruhi PGV secara langsung adalah HT. Peubah-peubah bebas lainnya memengaruhi PGV secara tidak langsung karena peubah bebas harus melalui peubah mediasi yaitu CM dan SP.
Masing-masing indikator peubah-peubah di atas memiliki nilai error yang dilambangkan dengan huruf e. Error dapat terjadi karena adanya kemungkinan terjadi masalah identifikasi seperti tidak bisa memberikan informasi, angka yang ekstrim, atau pun korelasi antar koefisien yang sangat tinggi. Hasil analisis dapat dilihat pada tabel 1 . Semua indikator mempunyai nilai maksimum 5, minimum1, dan batas 4 .

Tabel 2. Hasil dari Merasakan Data $(n=180)$

\begin{tabular}{ccccccc}
\hline Indikator & $\begin{array}{c}\text { Rata- } \\
\text { Rata }\end{array}$ & Rerata & Maksimum & Minimum & $\begin{array}{c}\text { Range } \\
\text { (Batas) }\end{array}$ & $\begin{array}{c}\text { Simpangan } \\
\text { baku }\end{array}$ \\
\hline PGV1 & 4,0444 & & 5 & 1 & 4 & 0,90203 \\
PGV2 & 3,8111 & 5 & 1 & 4 & 1,03992 \\
PGV3 & 3,9833 & & 5 & 1 & 4 & 1,02197 \\
PGV4 & 3,5278 & 3,6095 & 5 & 1 & 4 & 1,15032 \\
PGV5 & 3,3000 & & 5 & 1 & 4 & 1,14774 \\
PGV6 & 3,0667 & 5 & 1 & 4 & 1,18934 \\
PGV7 & 3,5333 & 5 & 1 & 4 & 1,15018 \\
\hline
\end{tabular}




\begin{tabular}{|c|c|c|c|c|c|c|}
\hline Indikator & $\begin{array}{l}\text { Rata- } \\
\text { Rata }\end{array}$ & Rerata & Maksimum & Minimum & $\begin{array}{l}\text { Range } \\
\text { (Batas) }\end{array}$ & $\begin{array}{c}\text { Simpangan } \\
\text { baku }\end{array}$ \\
\hline HT1 & 3,7722 & \multirow{3}{*}{3,6222} & 5 & 1 & 4 & 1,04550 \\
\hline HT2 & 3,5944 & & 5 & 1 & 4 & 1,04479 \\
\hline HT3 & 3,5000 & & 5 & 1 & 4 & 1,08571 \\
\hline G1 & 3,7278 & \multirow{4}{*}{3,6889} & 5 & 1 & 4 & 1,00741 \\
\hline $\mathrm{G} 2$ & 3,9611 & & 5 & 1 & 4 & 0,95931 \\
\hline G3 & 3,9611 & & 5 & 1 & 4 & 0,99924 \\
\hline G4 & 3,1056 & & 5 & 1 & 4 & 1,20287 \\
\hline KST1 & 3,8722 & \multirow{5}{*}{3,6833} & 5 & 1 & 4 & 0,95736 \\
\hline KST2 & 3,6833 & & 5 & 1 & 4 & 1,08043 \\
\hline KST3 & 3,6889 & & 5 & 1 & 4 & 1,09488 \\
\hline KST4 & 3,6222 & & 5 & 1 & 4 & 1,09420 \\
\hline KST5 & 3,5500 & & 5 & 1 & 4 & 1,12003 \\
\hline RVT1 & 4,0056 & \multirow{6}{*}{4,0620} & 5 & 1 & 4 & 0,91234 \\
\hline RVT2 & 4,2056 & & 5 & 1 & 4 & 0,93771 \\
\hline RVT3 & 4,1944 & & 5 & 1 & 4 & 0,83964 \\
\hline RVT4 & 3,9778 & & 5 & 1 & 4 & 1,01363 \\
\hline RVT5 & 4,2000 & & 5 & 1 & 4 & 0,88058 \\
\hline RVT6 & 3,7889 & & 5 & 1 & 4 & 1,06225 \\
\hline KT1 & 3,5056 & \multirow{6}{*}{3,5722} & 5 & 1 & 4 & 1,14090 \\
\hline KT2 & 3,6889 & & 5 & 1 & 4 & 1,07427 \\
\hline KT3 & 3,5667 & & 5 & 1 & 4 & 1,09901 \\
\hline KT4 & 3,4722 & & 5 & 1 & 4 & 1,08535 \\
\hline KT5 & 3,5556 & & 5 & 1 & 4 & 1,04759 \\
\hline KT6 & 3,6444 & & 5 & 1 & 4 & 1,07601 \\
\hline CM1 & 3,7722 & \multirow{2}{*}{3,7111} & 5 & 1 & 4 & 1,12280 \\
\hline $\mathrm{CM} 2$ & 3,6944 & & 5 & 1 & 4 & 1,17277 \\
\hline CM3 & 3,6556 & & 5 & 1 & 4 & 1,06924 \\
\hline CM4 & 3,9167 & & 5 & 1 & 4 & 0,96807 \\
\hline CM5 & 3,5167 & & 5 & 1 & 4 & 1,09583 \\
\hline SP1 & 3,6222 & \multirow{5}{*}{3,4789} & 5 & 1 & 4 & 0,98114 \\
\hline SP2 & 3,4167 & & 5 & 1 & 4 & 1,05637 \\
\hline SP3 & 3,2722 & & 5 & 1 & 4 & 1,14253 \\
\hline SP4 & 3,3667 & & 5 & 1 & 4 & 1,10812 \\
\hline SP5 & 3,7167 & & 5 & 1 & 4 & 1,08455 \\
\hline
\end{tabular}

Sumber: Data diolah (2017)

Keterangan: PGV = Penggunaan Gerai Virtual, HT = Harga-Terpersepsi, G = Getok-Tular, KST = Kualitas-Situs-Terpersepsi, Reputasi-Vendor-Terpersepsi, KT = Keterjaminan Struktural, CM

$=$ Citra Merek, SP $=$ Sikap Pembeli 
Peubah gayut memiliki nilai ratarata terbesar 4,0444 yang diwakili pada PGV1. Indikator-indikator dari tiap peubah bebas yang memiliki nilai rata-rata terbesar yaitu HT1, G2, G3, KST1, RVT2 dan KT2 dengan masing-masing nilai sebesar 3.7722, 3.9611, 3.9611, 3.8722, 4.2056 dan 3.6889. Ada pula indikator peubah mediasi CM4 dan SP5 memiliki nilai rata-rata terbesar senilai 3.9167 dan 3.7167. Nilai rata-rata terbesar mencerminkan bahwa data bervariasi dari satu sampel ke lainnya. Ada pun nilai maksimum dan minimum pada tabel 1 digunakan untuk menentukan range (batas). Masing-masing indikator dari peubah-peubah gayut, peubah bebas dan peubah mediasi memiliki nilai maksimum dan minimum yang sama yaitu 5 dan 1 , sehingga memiliki nilai batas yang sama senilai 4. Hal ini mencerminkan bahwa penyebaran data satu sampel ke lainnya untuk masing-masing indikator sama.

Namun keberagaman data yang didapatkan dari responden yang mayoritas generasi Y, laki-laki, dan memiliki pengeluaran pendapatan antara $\mathrm{Rp}$ 500.000,- hingga Rp 1.500.000,- untuk masing-masing indikator adalah berbeda. Indikator yang memiliki data paling beragam dari semua peubah adalah PGV6, HT3, G4, KST5, RVT6, KT1, CM2 dan SP3 karena masing-masing memiliki nilai simpangan baku terbesar yaitu 1,18934, $1.08571,1.20287,1.12003,1.06225$, $1.14090,1.17277$ dan 1.14253. Nilai rerata mencerminkan hasil jawaban ketika sudah diketahui rentang skala untuk rerata ini. Rentang skala untuk rerata ini adalah 0.8 . Nilai rerata untuk indikator semua peubah masing-masing memiliki nilai sebesar $3.6095,3.6222,3.6889,3.6833,4.0620$, 3.5722 , 3.7111, dan 3.4789. Masing-masing dari nilai rerata untuk semua indikator peubah penelitian ini berada pada rentang skala 3,41 sampai dengan 4,2. Hal ini menandakan bahwa mayoritas responden setuju dengan indikator-indikator dari peubah yang digunakan dalam penelitian ini.

\section{Hasil Kelayakan Model Awal}

Berikut ini merupakan hasil kelayakan model penelitian awal dengan menggunakan SEM. Tabel 3 berisikan kelayakan model berdasarkan 3 ukuran goodness of fit. 
Tabel 3. Hasil Kelayakan Model Awal ( $n=180)$

\begin{tabular}{cccc}
\hline $\begin{array}{c}\text { Ukuran Kelayakan } \\
\text { Model }\end{array}$ & Hasil & Nilai & Moderat/ Buruk \\
\hline \multirow{4}{*}{ Absolute Fit Indices } & Chi Square & 0,000 & Buruk \\
& GFI & 0,603 & Buruk \\
& RMSEA & 0,114 & Buruk \\
\hline \multirow{4}{*}{ Incremental Fit Indices } & AGFI & 0,530 & Buruk \\
& NFI & 0,603 & Buruk \\
& CFI & 0,682 & Buruk \\
& IFI & 0,685 & Buruk \\
& RFI & 0,578 & Buruk \\
\hline \multirow{4}{*}{ Parsimony Fit Indices } & AIC & $2.745,697$ & Buruk \\
& CAIC & $3.123,063$ & Moderat \\
& ECVI & 15,339 & Buruk \\
& PGFI & 0,518 & Buruk \\
\hline
\end{tabular}

Sumber: Data diolah (2017)

Keterangan: GFI $=$ Goodness of Fit, RMSEA = Root Mean Square Error of Approximation, AGFI $=$ Adjusted Goodness of Fit, $\mathrm{NFI}=$ Normal Fit Index, CFI = Comparative Fit Index, $\mathrm{IFI}=$ Incremental Fit Index, RFI = Relative Fit Indices, AIC = Akaike's Information Criterion, $\mathrm{CAIC}=$ Consistent Akaike Information Index, ECVI $=$ Expected Cross Validation Index dan PGFI = Parsimonious Goodness of Fit Index.

Hasil kelayakan model pada tabel 3 di atas menunjukkan bahwa nilai chi square sebesar 0,000 kurang dari nilai probabilitas yaitu 0,05 (buruk). Hal ini mencerminkan bahwa adanya penyimpangan antara matriks kovarian sampel dan matriks kovarian model. Hasil yang lain adalah GFI sebesar 0,603 dinyatakan buruk karena nilai lebih dari nilai fit model-nya yaitu 0,70 (Hair et. al. (2012)). Hal ini mencerminkan bahwa tingkat kesesuaian model secara keseluruhan yang dihitung dari nilai residu kuadrat adalah buruk. Ada pula RMSEA sebesar 0,114 yang buruk. Nilai RMSEA melebihi batas nilai fit model-nya yaitu 0,05-0,08. RMSEA yang buruk maka menandakan bahwa nilai parameter suatu model dengan matriks kovarian populasinya adalah buruk.

Ukuran kelayakan model yang kedua adalah incremental fit indices. Ukuran tersebut diwakili oleh AGFI NFI, CFI, IFI serta RFI. Semua kriteria dinyatakan buruk karena nilainya kurang dari nilai fit model-nya yaitu 0,70 . AGFI, IFI dan RFI masing-masing memiliki nilai sebesar 0,$530 ; 0,685$ dan 0,578. NFI sebesar 0,603 merupakan ukuran perbandingan antara proposed model dengan null model. CFI sebesar 0,682 merupakan ukuran perbaikan dari NFI yang tidak dipengaruhi ukuran sampel. Lalu ukuran kelayakan model yang terakhir adalah parsimony fit indices. AIC sebesar 2.745,697 dikatakan buruk karena memiliki nilai default model yang lebih dari nilai AIC saturated model. CAIC dikatakan moderat karena memiliki nilai default model yang kurang dari nilai CAIC saturated model dan independence model sebesar 3.123,063. ECVI sebesar 15,339 dikatakan buruk karena memiliki nilai default model yang lebih dari nilai ECVI saturated model. Hal ini berarti bahwa rawan terjadi penyimpangan antara matriks kovarian model yang layak untuk suatu sampel dengan sampel lainnya. Selain itu, PGFI memiliki nilai sebesar 0,518 . Nilai ini 
tidak memenuhi kelayakan karena kurang dari nilai probabilitasnya yaitu 0,60 . Hal ini mencerminkan bahwa dengan model penelitian yang sederhana tidak dapat menjelaskan fenomena yang ada di masyarakat dalam menggunakan gerai virtual. Mayoritas ukuran kelayakan model di atas yaitu terwakili dengan predikat buruk. Oleh karena itu, peneliti akan melakukan perubahan model sehingga model akhir lebih baik dan layak untuk diuji dengan menggunakan SEM.

\section{Model Penelitian Seusai Diuji SEM}

Gambar 3 merupakan model penelitian yang telah melalui proses uji SEM menggunakan program Amos 2.20

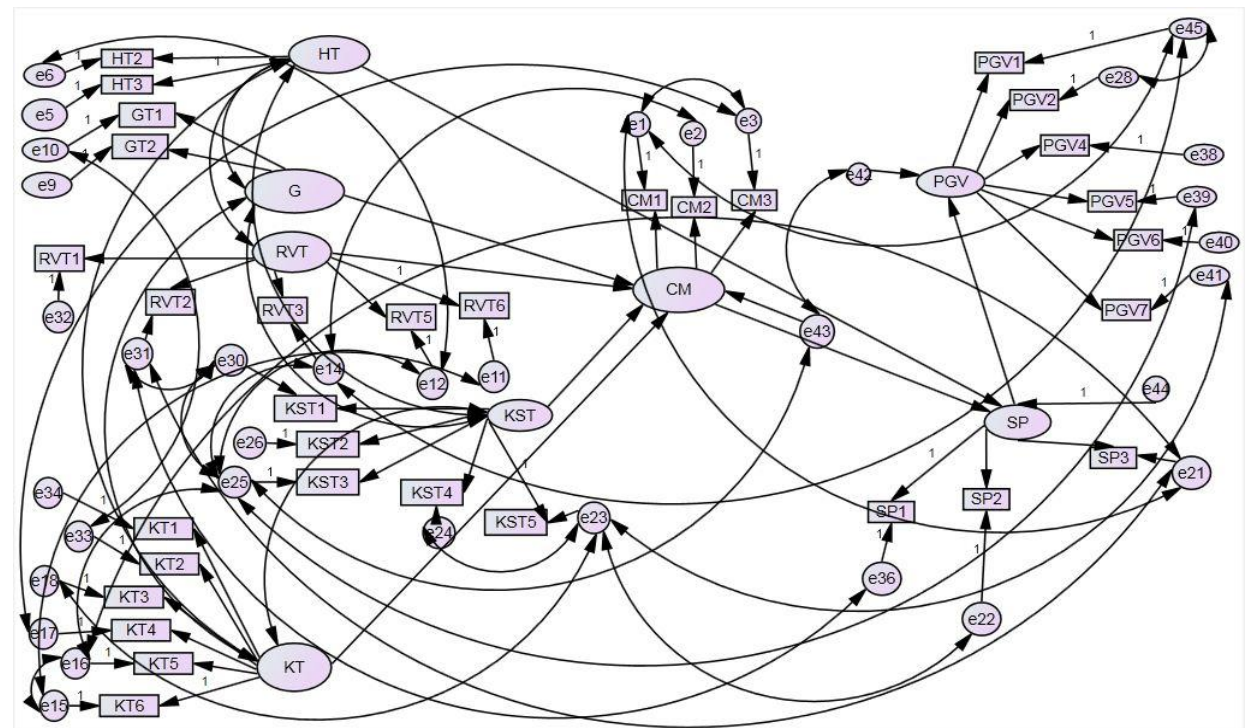

Gambar 6. Model Penelitian Seusai Diuji SEM $(n=180)$

Sumber: Data diolah (2017)

Keterangan: PGV = Penggunaan Gerai Virtual, HT = Harga-Terpersepsi, G = Getok-Tular, KST = Kualitas-Situs-Terpersepsi, Reputasi-Vendor -Terpersepsi, KT = Keterjaminan Struktural, CM $=$ Citra Merek, $\mathrm{SP}=$ Sikap Pembeli

Model ini merupakan model yang telah dimodifikasi hubungan antar peubah penelitian karena model awal penelitian buruk. Model ini berisi data indikator terakhir yang telah dihapus. Model ini berisi kaitan antara peubah bebas dan gayut, serta ada pula keterhubungan antara peubah bebas dengan peubah mediasi. Peubah gayut pada model penelitian ini adalah PGV. Peubah bebas untuk model penelitian ini yaitu HT, G, KST, RVT, dan KT, sedangkan peubah mediasinya yaitu CM dan SP. Setelah diolah, maka ada perubahan model penelitian dengan model awalnya.
Peubah bebas HT kini harus melalui SP terlebih dahulu sebelum memengaruhi PGV. Hal ini dikarenakan responden seharusnya berpikir dahulu sebelum bertindak dalam membeli produk fesyen. Lalu peubah bebas lainnya yaitu G, KST, RVT, dan KT harus melalui peubah mediasi CM sebelum pada akhirnya memengaruhi PGV. Hal ini timbul karena peubah bebas tersebut jika memiliki tingkat promosi, kualitas, reputasi, dan keamanan yang tinggi maka akan membentuk citra merek yang semakin positif. Citra merek akan memengaruhi sikap pembeli sebelum akhirnya memengaruhi penggunaan gerai virtual. Citra merek yang positif akan 
cenderung mendorong masyarakat untuk membeli produk fesyen di gerai virtual. Selain itu, masing-masing error pada indikator saling dihubungkan dengan tujuan agar model penelitian ini fit atau moderat.

\section{Hasil Kelayakan Model Akhir}

Berikut ini merupakan hasil kelayakan model penelitian akhir dengan menggunakan SEM. Tabel 4 berisi hasil kelayakan model berdasarkan 3 ukuran goodness of fit.

Tabel 4. Hasil Kelayakan Model $(n=180)$

\begin{tabular}{cccc}
\hline $\begin{array}{c}\text { Ukuran Kelayakan } \\
\text { Model }\end{array}$ & Hasil & Nilai & Moderat/ Buruk \\
\hline \multirow{4}{*}{ Absolute Fit Indices } & Chi Square & 0,000 & Buruk \\
& GFI & 0,795 & Moderat \\
& RMSEA & 0,077 & Moderat \\
\hline \multirow{4}{*}{ Incremental Fit Indices } & AGFI & 0,745 & Moderat \\
& NFI & 0,821 & Moderat \\
& CFI & 0,897 & Moderat \\
& IFI & 0,899 & Moderat \\
& RFI & 0,790 & Moderat \\
\hline \multirow{4}{*}{ Parsimony Fit Indices } & AIC & $1.083,749$ & Buruk \\
& CAIC & $1.524,010$ & Moderat \\
& ECVI & 6.054 & Buruk \\
& PGFI & 0.637 & Moderat
\end{tabular}

Sumber: Data diolah (2017)

Keterangan: GFI $=$ Goodness of Fit, RMSEA $=$ Root Mean Square Error of Approximation, AGFI $=$ Adjusted Goodness of Fit, $\mathrm{NFI}=$ Normal Fit Index, $\mathrm{CFI}=$ Comparative Fit Index, IFI $=$ Incremental Fit Index, RFI = Relative Fit Indices, AIC = Akaike's Information Criterion, CAIC $=$ Consistent Akaike Information Index, ECVI $=$ Expected Cross Validation Index dan PGFI $=$ Parsimonious Goodness of Fit Index.

Hasil kelayakan model pada tabel 4 di atas menunjukkan bahwa nilai chi square sebesar 0,000 kurang dari nilai probabilitas yaitu 0,05 (buruk). Hasil yang lain adalah GFI sebesar 0,79 yang dinyatakan moderat karena nilai lebih dari nilai fit model-nya yaitu 0,70 (Hair et al., 2012). Selain 2 kriteria di atas, ada pula RMSEA sebesar 0,077. RMSEA merupakan nilai parameter suatu model dengan matriks kovarian populasinya. Nilai RMSEA memenuhi kelayakan model karena nilainya berkisar pada angka 0,05-0,08. Ukuran kelayakan model yang kedua adalah incremental fit indices. Ukuran ini memenuhi 5 buah kriteria kelayakan model yaitu AGFI NFI, CFI, IFI serta RFI. Semua kriteria dinyatakan moderat karena nilainya melebihi nilai fit model-nya yaitu 0,70 .

Ukuran kelayakan model yang terakhir adalah parsimony fit indices. AIC sebesar 1.083,749 dikatakan buruk karena memiliki nilai default model yang lebih dari nilai AIC saturated model. CAIC dikatakan moderat karena memiliki nilai default model yang kurang dari nilai CAIC saturated model dan independence model sebesar 1.524,010. ECVI sebesar 6.054 dikatakan buruk karena memiliki nilai default model yang lebih dari nilai ECVI saturated model. Hal ini berarti bahwa rawan terjadi penyimpangan antara matriks kovarian model yang layak untuk suatu sampel dengan sampel lainnya. Selain itu, 
PGFI memiliki nilai sebesar 0,637. Nilai ini memenuhi kelayakan karena melebihi nilai probabilitasnya yaitu 0,60 . Hal ini mencerminkan bahwa dengan model penelitian yang sederhana dapat menjelaskan fenomena yang ada di masyarakat dalam menggunakan gerai virtual.

\section{Hasil Uji Hipotesis}

Tabel 5 di bawah ini berisikan hasil uji hipotesis mengenai model penelitian akhir dengan menggunakan SEM. P-value pada uji hipotesis ini dibagi ke dalam 3 golongan. Hipotesis dikatakan diterima apabila nilai $p$-value nya di bawah nilai signifikansinya yaitu $0.01,0.05$ dan 0.1

Tabel 5. Hasil Uji Hipotesis Akhir $(\mathbf{n}=180)$

\begin{tabular}{ccc}
\hline Hipotesis & P-Value & Hipotesis Diterima/ Ditolak \\
\hline HT $\square \mathrm{SP}$ & $* * *$ & Hipotesis diterima \\
$\mathrm{G} \square \mathrm{CM}$ & 0,626 & Hipotesis ditolak \\
$\mathrm{RVT} \square \mathrm{CM}$ & $* * *$ & Hipotesis diterima \\
$\mathrm{KST} \square \mathrm{CM}$ & 0,382 & Hipotesis ditolak \\
$\mathrm{KT} \square \mathrm{CM}$ & $* *$ & Hipotesis diterima \\
$\mathrm{CM} \square \mathrm{SP}$ & $* * *$ & Hipotesis diterima \\
$\mathrm{SP} \square \mathrm{PGV}$ & $* * *$ & Hipotesis diterima \\
\hline
\end{tabular}

Sumber: Data diolah (2017)

Keterangan: PGV = Penggunaan Gerai Virtual, HT = Harga-Terpersepsi, G = Getok-Tular, KST = Kualitas-Situs-Terpersepsi, Reputasi-Vendor-Terpersepsi, KT = Keterjaminan Struktural, CM $=$ Citra Merek, SP $=$ Sikap Pembeli

Catatan: Golongan pertama adalah $* * *$, artinya adalah $p$-value di bawah tingkat siginifikasi sebesar 0.01 . Golongan kedua adalah $* *$, artinya adalah $p$-value di bawah tingkat signifikansi sebesar 0.05 . Golongan ketiga adalah *, artinya adalah $p$-value di bawah tingkat signifikansi sebesar 0.1 .

Berdasarkan tabel 5 di atas, hipotesis pada model penelitian akhir dengan menggunakan SEM kini berjumlah 7 buah. Keempat hipotesis diterima dan memiliki predikat bintang $3(* * *)$ yang artinya nilai $p$-value-nya di bawah tingkat signifikansi 0.01 atau $1 \%$. Mayoritas responden yang merupakan generasi $\mathrm{Y}$, laki-laki, dan memiliki pengeluaran pendapatan antara Rp 500.000,- hingga $\mathrm{Rp}$ 1.500.000,- setuju bahwa sikap pembeli dipengaruhi oleh harga-terpersepsi. Hasil penelitian yang baru ini sejalan dengan Nurtjahjanti (2012) mengenai dampak positif harga-terpersepsi dan kualitas produk minat beli Mahasiswa Politeknik X Semarang untuk produk fesyen di dagang elektronik. Penelitian juga sejalan dengan Hariadi (2012) yang menemukan bahwa produk, harga-terpersepsi, promosi dan distribusi secara bersama mau pun parsial memengaruhi keputusan beli untuk produk projector microvision. Penilaian pelanggan mengenai jumlah uang yang akan dikeluarkan demi mendapatkan manfaat produk akan memengaruhi emosi dan sikap pelanggan. Harga produk yang tinggi akan mendorong pembeli untuk tidak menggunakan gerai virtual dalam berbelanja produk fesyen.

Mayoritas responden juga setuju bahwa citra merek dipengaruhi oleh reputasi-vendor-terpersepsi. Hal ini sejalan dengan penelitian Ping (2012) yaitu " $E$ Marketing Development in Virtual MarketSpace: A Strategi Perspective". Teknologi meliputi proses jasa yang cepat, produk virtual, personalisasi, interaksi, dan komunikasi banyak arah akan mengubah sistem pemasaran gerai virtual lebih baik 
ketimbang gerai riil. Hal tersebut akan membuat reputasi vendor lebih baik sehingga dagang elektronik akan lebih maju. Reputasi-vendor-terpersepsi yang baik akan memberikan keyakinan kepada pihak lain mengenai kemampuan, integritas dan goodwill. Oleh karena itu, reputasivendor-terpersepsi akan menciptakan citra merek.

Mayoritas responden juga setuju bahwa sikap pembeli dipengaruhi citra merek. Hal ini sejalan dengan penelitian Rahma (2007) yang menemukan bahwa citra merek dan kualitas layanan berpengaruh terhadap minat pembeli, sehingga mendorong keputusan beli. Citra merek yang baik akan mendorong pembeli bereaksi positif terhadap merek tersebut. Pembeli akan cenderung menyukai geraigerai virtual yang telah terkenal baik dalam layanannya. Mayoritas responden juga setuju bahwa penggunaan gerai virtual dipengaruhi oleh sikap pembeli. Kim et al. (2008) menjelaskan bahwa sikap pembeli merupakan faktor penting dalam proses pengambilan keputusan beli daring. Kesukaan pembeli terhadap toko daring dengan memperkirakan manfaat yang akan diterima akan memengaruhi pembeli ke sikap yang positif mau pun negatif. Sikap pembeli yang positif akan mendorong pembeli menggunakan gerai virtual untuk berbelanja produk fesyen.

Berdasarkan Tabel 5 di atas, dapat diketahui pula bahwa mayoritas responden yang merupakan generasi Y, laki-laki, dan memiliki pengeluaran pendapatan antara $\mathrm{Rp}$ 500.000,- hingga Rp 1.500.000,- setuju bahwa citra merek dipengaruhi oleh keterjaminan struktural (tingkat kepercayaan 95\%). Hal ini sejalan dengan penelitian Pujastuti et al. (2014) berjudul "Pengaruh E-Commerce Gerai Online Fashion terhadap Kepercayaan Konsumen" menemukan bahwa kepercayaan konsumen dagang elektronik fesyen di Indonesia sangat dipengaruhi oleh kualitas situs dan keterjaminan struktural. Keamanan yang baik dan kuat berguna demi menyukseskan penjual karena hal tersebut akan membentuk suatu citra merek yang positif.
Namun ada 2 buah hipotesis yang ditolak oleh mayoritas responden karena tidak setuju yaitu citra merek dipengaruhi oleh getok-tular dan kualitas-situsterpersepsi. Hal ini tidak sejalan dengan temuan bahwa promosi akan memengaruhi konsumen karena produsen yang menyampaikan pesan pada produknya akan membuat konsumen mengenal produk dan meyakinkan pembeli bahwa produk yang dibeli memberikan manfaat kepada mereka (Sumarwan, 2011). Komunikasi yang dibutuhkan untuk memromosikan gerai virtual ke pembeli adalah dengan GT-e (getok-tular-elektronik). Komunikasi melalui media sosial dari penjual atau kelompok acuan yang baik akan membentuk citra merek gerai virtual yang baik pula.

Mayoritas responden tidak setuju dengan citra merek dipengaruhi oleh kualitas-situs-terpersepsi karena mereka berpikir kualitas meliputi desain dan konten bisa saja tidak mencerminkan kondisi gerai virtual yang sebenarnya. Hal ini tidak sejalan dengan penelitian Puspitasari et al. (2014) yang menemukan kualitas situs memiliki pengaruh terhadap nilai yang dipersepsikan, kepuasan dan kesetiaan pelanggan, serta Hyejeong dan Niehm (2009) yang menemukan bahwa konsumen yang percaya pada informasi situs, maka akan berpikir produk daring layak untuk dibeli. Pembeli di sini tidak menilai kualitas situs gerai virtual dan desain konten situs baik secara informasi atau pun grafisnya. Responden hanya memikirkan hal-hal lain seperti harga, keamanan, reputasi gerai virtual dalam melakukan keputusan beli.

\section{SIMPULAN, IMPLIKASI, KETERBATASAN DAN SARAN}

\section{Simpulan}

Berdasarkan hasil dan pembahasan sebelumnya, maka dapat disimpulkan bahwa sikap pembeli dipengaruhi secara langsung oleh harga-terpersepsi. Besarnya nilai sikap pembeli yang dipengaruhi secara langsung oleh harga-terpersepsi adalah 
17,5\%. Lalu besarnya nilai citra merek dipengaruhi oleh reputasi-vendorterpersepsi adalah $8,3 \%$. Selain itu, sikap pembeli dipengaruhi oleh citra merek. Besarnya nilai sikap pembeli dipengaruhi oleh citra merek adalah 52,8\%. Penggunaan gerai virtual yang dipengaruhi oleh sikap pembeli memiliki nilai pengaruh sebesar $81,9 \%$. Namun dapat diketahui pula bahwa citra merek tidak dipengaruhi oleh getoktular dan kualitas-situs-terpersepsi. Masingmasing besar nilai pengaruh citra merek dengan getok-tular dan kualitas-situsterpersepsi adalah $4,9 \%$ dan $56,7 \%$.

\section{Implikasi Penelitian}

Penelitian ini memberikan manfaat bagi perusahaan di bidang fesyen virtual. Pengusaha gerai virtual diharapkan mampu memanfaatkan informasi mengenai apa saja yang memengaruhi pembeli dalam menggunakan gerai virtual fesyen. Pengusaha yang mampu menganalisis perilaku konsumen yang baik akan mampu merancang strategi pemasaran untuk meningkatkan kinerja perusahaan. Strategi pemasaran yang dilakukan diharapkan mampu mengembangkan dan meningkatkan layanan dan kualitas gerai virtual. Selain itu, pengusaha diharapkan mampu membuat pembeli setia terhadap gerai virtual fesyen mereka.

\section{Keterbatasan dan Saran Penelitian}

Penelitian ini tidak luput dari keterbatasan. Keterbatasan penelitian ini adalah peneliti tidak spesifik ke suatu atau dua gerai virtual fesyen tertentu saja. Peneliti hanya melihat dan menguji fenomena yang ada secara umum. Sampel penelitian yang diambil berisikan generasi $\mathrm{X}$ hingga $\mathrm{Z}$, responden hanya diambil pada satu wilayah saja. Lalu peubah-peubah yang memengaruhi penggunaan gerai virtual bisa saja ada yang tidak tercantumkan dalam penelitian ini. Saran untuk penelitian serupa selanjutnya adalah menggunakan objek penelitian yaitu gerai virtual yang lebih spesifik. Selain itu, pengambilan sampel jika dimungkinkan berada di 2 wilayah yang berbeda. Hal tersebut dilakukan untuk membandingkan perilaku konsumen tiap wilayah berbeda atau tidak dalam menanggapi, memilih dan menggunakan gerai virtual fesyen tertentu. Selain itu, peneliti selanjutnya dapat menambahkan peubah-peubah baru dalam model penelitian ini.

\section{DAFTAR PUSTAKA}

Arfani, Riza Noer. (2004). Globalisasi: Karakteristik dan Implikasinya, Ekonomi Politik Digital Journal AlManar. Edisi I Tahun 2004.

Assegaff, Setiawan. (2009). Strategi Pengembangan Situs Pemerintah Daerah sebagai Sarana Pelayanan Publik Berbasis Web. Jurnal Media Sisfo. Vol. 3 No. 1 Februari 2009.

Bigne, J. Enrique. (2008). The Impact of Experiential Consumption Cognitions and Emotions on Behavioral Intentions. Amerika Serikat: Emerald.

Breckler, S. J. (1984). Empirical Validation of Affect, Behaviour, and Cognition as Distinct Components of Attitude. Journal of Personality and Social Psychology.Dawn, S. K. dan U., Kar. (2011). E-Tailing in India: Its Issues, Opportunities and Effective Strategies For Growth and Development. International Journal of Multidisciplinary Research. Vol. 1 Issue 3, July 2011. ISSN 22315780.

Ebert, R. J., dan Griffin, R. W. (2011). Business Essentials. $8^{\text {th }}$ Ed. Amerika Serikat: Pearson Education.

Florenthal, Bela. (2007). Matching ETailing Strategies to Customer's Behavior: Three Level of Interaction. Journal of Business and Public Affairs. Vol. 1. ISSN: 1934-7219. 
Gupta, V. (2013). An Empirical Study to Customer Satisfaction Level For ETailing Using ASCI's Model. International Journal of Advance Research in Computer Science and Management Studie. Vol. 1 Issue 6, November 2013. ISSN 2321-7782.

Hair, Joseph F. Jr., dkk. (2012). Multivariate Data Analysis: A Global Perspective. Amerika Serikat: Pearson.

Hajli, M. Nick. (2014). A Study of The Impact of Social Media on Consumers. International Journal of Market Research. Vol. 56.

Hariadi, Doni. (2012). Pengaruh Produk, Harga, Promosi dan Distribusi terhadap Keputusan Pembelian Konsumen pada Produk Projector Microvision. Ejournal.stiesia.ac.id. Vol. 1 No. 8 Tahun 2012.

Hyejeong, Kim dan Niehm, Linda S. (2009). The Impact of Website Quality on Information Quality, Value, and Loyalty Intentions in Apparel Retailing. Journal of Interactive Marketing. Vol. 23. ISSN: 1094-9968.

Jarvenpaa, Sirkka L., Tractinsky, Noam, dan Vitale, Michael. (2000). Consumer Trust in An Internet Store. Information Technology and Management I. Baltzer Science Publishers BV.

Jatmika, Chandra Sukka. (2014). Pengaruh Electronic Word of Mouth terhadap Brand Image dan Purchase Intention Samsung di Surabaya. Jurnal Ilmiah Mahasiswa Surabaya. Vol. 3 No. 2.

Javadi, M. H. Moshref, dkk. (2012). An Analysis of Factors Affecting on Online Shopping Behavior of Consumers. International Journal of Marketing Studies.

Josang, Audun. (2007). Trust and Reputation System. Foundations of Security Analysis and Design IV.

Kalakota, Ravi dan Whinston, Andrew B. (1997). Electronic Commerce: A Manager's Guide. $1^{\text {st }}$ Edition.
Kim, D. J., Ferrin, D. L., dan Rao, H. R. (2008). A Trust-Based Consumer Decision-Making Model in Electronic Commerce: The Role of Trust. Perceived Risk, and Their Antecedents. Decision Support Systems. Vol. 44. Elsevier. Belgia

Kotler, P. dan Keller K. L. (2013). Marketing Management. $14^{\text {th }}$ Ed. Amerika Serikat: Pearson.

Latan, Hengky. (2012). Structural Equation Modelling: Konsep dan Aplikasi Menggunakan Program LISREL 8.80. Bandung: Alfabeta

Laudon dan Laudon. (1998). E-Commerce: Definisi, Jenis, Tujuan, Manfaat dan Ancaman Menggunakan ECommerce. $\quad$ http://jurnalsdm.blogspot.co.id

Luntungan, Irving, Hubeis, Aida Vitayala S., Sunarti, Euis, dan Maulana, Agus. (2014). Strategi Pengelolaan Generasi Y di Industri Perbankan. Jurnal Manajemen Teknologi. Vol. 13 No. 2 2014. ISSN: 1412-1700

Mantansari, Alens Diana. (2015). Perilaku Brand Switching (Perubahan Merek) padaTelepon Seluler yang Dipengaruhi Oleh Reference Group (Kelompok Acuan) (Studi pada Mahasiswa Psikologi Universitas Brawijaya Malang). Universitas Brawijaya Malang.

Mira, Serafina. (2013). Hubungan Antara Citra Perusahaan dengan Tingkat Kepercayaan Pelanggan (Studi Kuantitatif pada Member Aktif Minimal Peringkat 12\% di Kantor Cabang Oriflame Yogyakarta,. Universitas Atma Jaya Yogyakarta.

Noviyarto, H. (2010). Pengaruh Perilaku Konsumen Mobile Internet terhadap Keputusan beli Paket Layanan Data Unlimited Internet CDMA di DKI Jakarta. Jurnal Telekomunikasi dan Komputer. Vol. 1. No. 2. 
Nurtjahjanti, Harlina. (2012). Hubungan Antara Persepsi terhadap Harga dan Kualitas Produk dengan Minat Membeli Produk Fashion Online Shop di Facebook pada Mahasiswa Politeknik X Semarang. Universitas Diponegoro Semarang.

Ping, H. Y. (2012). E-Marketing Development in Virtual MarketSpace: A Strategic Perspective. Asian Journal of Business Management 4. ISSN: 2041-8752.

Prasad, C. dan Aryasri, A. (2009). Determinants of Shopper Behavior in E-Tailing: An Empirical Analysis. Paradigm.

Pujastuti, E., W. W. Winarno, dan Sudarmawan. (2014). Pengaruh ECommerce Gerai Online Fashion terhadap Kepercayaan Konsumen. Citec Journal. Vol. 1 No. 2. ISSN: 2354-5771.

Rumlus, Katharina Wieneke dan Junaedi, Shellyana. (2014). Pengaruh Risiko-Risiko Pembelian pada Sikap dan Perilaku Pembelian secara Online. Universitas Atma Jaya Yogyakarta.

Sangadji, Etta M. dan Sopiah. (2013). Perilaku Konsumen: Pendekatan Praktis. Yogyakarta: Andi Offset.

Sekretariat ASEAN. (2008). Asean Economic Community Blueprint. ISBN 978-979-3496-77-1.

Sha, Wei. (2009). Types of Structural Assurance and Their Relationships with Trusting Intentions in Business-to-Consumer ECommerce. Electronic Markets. Vol. 19.

Shim, J. P., Shin, Y. B., dan Nottingham, L. (2002). Retailer Web Site Influence on Customer Shopping: An Exploratory Study in Key Factors of Customer Satisfaction. Journal of The Association for Information Systems.

Subiantara, Bima Pratama dan Sukoharsono, Eko Ganis. (2014). Pengaruh Structural Assurance dan Perceived Reputation terhadap
Trust Pengguna Internet di Sistem E-Commerce, Universitas Brawijaya Malang.

Subianto, T. (2007). Studi tentang Perilaku Konsumen Beserta Implikasinya terhadap Keputusan beli. Jurnal Ekonomi Modernisasi. Vol. 3. No. 3. Oktober 2007.

Sukma, Kadek Ayu Dwi Sudias Kumala, Nurcahya, I Ketut, dan Suryani, Alit. (2016). Pengaruh Celebrity Endorser, Brand Image dan Kepercayaan terhadap Keputusan Pembelian Produk Pembersih Wajah Men's Biore. E-Jurnal Manajemen Unud. Vol. 5 No. 7. ISSN: 2302-8912.

Sumardi. (2009). Mencintai Negatif Word of Mouth, SWA Edisi XXV Juni 2009.

Sumarwan, Ujang. (2011). Perilaku Konsumen. Bogor: Ghalia Indonesia.

Turban, E., King, D., Lee, J., dan Viehland, D. (2008). Electronic Commerce: A Managerial Perspective. Amerika Serikat: Pearson Education.

Widiyanto, Ibnu dan Prasilowati, Sri Lestari. (2015). Perilaku Pembelian Melalui Internet. Jurnal Manajemen dan Kewirausahaan. Vol. 17 No. 2 September 2015. ISSN: 1411-1438.

Xia, L., Monroe, K. B., dan Cox, J. L. (2004). The Price Is Unfair! A Conceptual Framework of Price Fairness Perceptions. Journal of Marketing.

Yu, T. dan Wu, G. (2007). Determinants of Internet Shopping Behavior: An Application of Reasoned Behavior Theory. International Journal of Management. Vol. 24 No. 4 Desember 2007.

Zhang, Yi. (2015). The Impact of Brand Image on Consumer Behavior: A Literature Review. Open Journal of Business and Management. Januari 2015. 